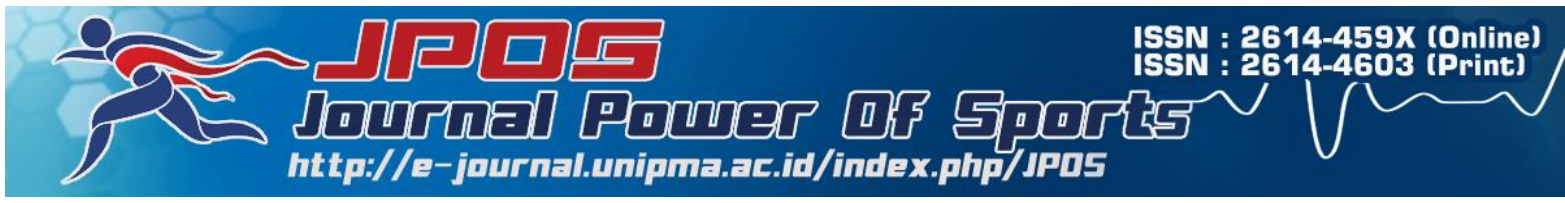

\title{
Pengembangan olahraga woodball di Provinsi Jawa Tengah
}

\author{
Mega Widya Putri ${ }^{1}$, Resty Agustriyani ${ }^{2}$, Sugiyanto $^{3}$, Kiyatno $^{4}$ \\ Universitas Sebelas Maret ${ }^{134}$, Universitas Siliwangi ${ }^{2}$, Indonesia \\ Email: megawidyaputri60@yahoo.com ${ }^{1}$, restyagustriyani@gmail.com ${ }^{2}$, \\ sugiyantoprobo@gmail.com ${ }^{3}$
}

\begin{abstract}
Abstrak
Penelitian ini bertujuan untuk: (1) Mengetahui keberadaan organisasi olahraga woodball di Provinsi Jawa Tengah. (2) Mengetahui upaya pengembangan cabang olahraga woodball yang dilakukan di Pengprov IWbA Jawa Tengah. (3) Mengetahui kondisi sumber daya manusia di Pengprov Jawa Tengah untuk mengembangkan olahraga woodball. (4) Mengetahui sarana dan prasarana yang dimiliki Pengprov Jawa Tengah. (5) Mengetahui penggalian sumber dana oleh Pengprov Jawa Tengah. (6) Mengetahui pembinaan prestasi olahraga woodball yang diterapkan di Pengprov Jawa Tengah. Penelitian ini dilakukan di Indonesia Woodball Association (IWbA) dan Pengprov IWbA Jawa Tengah. Metode yang digunakan adalah deskriptif kualitatif dengan subyek penelitian Pengembangan olahraga woodball di Provinsi Jawa Tengah. Sumber data berupa wawancara dan catatan-catatan mengenai organisasi, sumber daya manusia, sarana prasarana, pendanaan dan pembinaan prestasi yang dimiliki oleh $I W b A$ dan pengurus Provinsi $I W b A$ Jawa Tengah dan informan dengan menggunakan teknik snowball sampling. Teknik pengumpulan data yang digunakan dalam penelitian ini yaitu mengkaji dokumen dan arsip (content analysis), wawancara mendalam (in-depth interviewing) dan observasi (observation). Hasil penelitian menunjukkan bahwa (1) Indonesia woodball association dan Pengprov $I W b A$ Jawa Tengah mempunyai peran penting dalam proses pengembangan olahraga woodball. (2) Pengprov IWbA Jawa Tengah telah melakukan berbagai upaya untuk mengembangkan olahraga woodball dengan melakukan sosialisasi, pelatihan dan pembinaan bagi pelatih dan atlet. (3) Sumber daya manusia di Pengprov IWbA Jawa Tengah mulai dari pengurus, pelatih dan juga atlet mempunyai potensi dan kualitas yang baik. Hal tersebut ditunjukkan oleh minat, bakat dan banyaknya prestasi yang diraih oleh atlet woodball Provinsi Jawa Tengah. (4) Sarana dan prasarana yang dimiliki oleh Pengprov Jawa Tengah sudah sesuai dengan kualitas dan kuantitas yang di tetapkan. Namun pada saat penggunaan fasilitas olahraga, Pengprov IWbA Jawa Tengah masih harus bekerja sama dengan beberapa pihak dikarenakan belum mempunyai fasilitas pribadi. (5) Penggalian sumber dana didapat dari KONI dan PB IWbA. Selama ini pemerintah belum turut serta dalam pengembangan olahraga woodball khususnya dalam bidang pendanaan. (6) Pengprov IWbA Jawa Tengah belum maksimal dalam melakukan pembinaan prestasi. Keterbatasan pendanaan mengakibatkan beberapa program pembinaan prestasi belum terlaksana dengan baik, seperti belum adanya pusat pelatihan atlet dan juga perekrutan atlet junior.
\end{abstract}

Kata Kunci : pengembangan; olahraga; woodball. 


\begin{abstract}
This study aims to (1) Figure out the existenceof woodball sports organization in the province of Central Java. (2) Determine the efforts in the development of sports woodball conducted in IWbA Central Java Pengprov. (3) Find out of the status of human resources in Central Java Pengprov to develop sports woodball. (4) Knowing facilities and infrastructure owned by Central Java Pengprov. (5) Find out the source of funds by Central Java Pengpov's excavation. (6) Knowing coaching achievements of woodball sports applied in Central Java Pengprov. This research was conducted in Indonesia Woodball Association (IWbA) and IWbA Central Java Pengprov. The method used was descriptive qualitative research with woodball Sports Development in Central Java province as subject of the research. Sources of data in the form of two data; first, interviews and records of the organization, human resources, infrastructure, funding and coaching achievements of the $I W b A$ and administrators IWbA province of Central Java and the second data was from informants, they both were gained by using snowball sampling technique. Data collection techniques used in this research were examining the documents and archives (content analysis), in-depth interviews (in-depth interviewing) and observations (observation). The results showed that (1) Indonesia woodball association and IWbA Central Java Pengprov had an important role in the process of woodball sport development. (2) IWbA Central Java Pengprov had made various efforts to develop the sport woodball with socialization, training and coaching for coaches and athletes. (3) Human resources in Central Java IWbAPengprov ranging from administrators, coaches and athletes also have the good potential and quality. This is shown by the interest, talent and the many accomplishments achieved by athletes' woodball in Central Java province. (4) Facilities and infrastructure owned by Pengprov Central Java were in accordance with the quality and quantity in the set. However, the use of the sports facilities, PengprovIWbA Central Java still needed to work with several parties due to itsless private facilities. (5) Excavation of funding sources were obtained from KONI and PB IWbA. So far the government had not participated in the development of sport woodball particularly in the areas of funding. (6) Pengprov IWbA Central Java did not maximize in fostering achievement. Limitations of funding resulted several achievements coaching program had not done well, such as the lack of a training center athletes and junior athlete's recruitment.
\end{abstract}

Keywords: development; sports; woodball

How To Cite : Putri W, M., Agustriyani R., Sugiyanto., Kiyatno. (2018). Pengembangan to APA Style olahraga woodball di Provinsi Jawa Tengah. JPOS (Journal Power Of Sports), 1 (1), 40-54.

\section{PENDAHULUAN}

Pengembangan olahraga tidak hanya dilakukan dengan bagaimana cara membina atlet supaya prestasinya dapat berkembang dengan baik, namun dapat dilihat dari manajemen kepengurusannya. Didalam manajemen kepengurusan dapat mengetahui keadaan perkembangan olahraga tersebut.

Ada berbagai faktor untuk melihat apakah olahraga tersebut sudah atau belum berkembang. Beberapa faktor diantaranya adalah, kita dapat melihat bagaimana organisasi dan manajemen yang menaungi, bagaimana sumberdaya manusia, sarana prasarana, pendanaan dan pembinaan 
prestasinya. Dari berbagai aspek tersebut kita bisa sedikit banyak mengetahui tentang perkembangan olahraga.

Proses pembinaan termasuk pelatihan olahraga selama ini sering dilakukan hanya berdasarkan pengalaman yang spekulatif dan intuitif, sehingga kurang efektif. Proses pencapaian prestasi dalam olahraga sebenarnya merupakan proses yang harus dapat diamati kemajuannya dan diukur hasilnya. Dalam konteks ini, jika pembinaan olahraga dilakukan dengan pendekatan ilmiah mulai dari fase pemasalan, pembibitan hingga proses pembinaan yang didukung sumber daya yang memadai (pelatih, sarana dan prasarana, dana, serta kompetisi), dengan disertai pula upaya mencermati para kompetitor, maka dapat dipastikan keberhasilannya. Dilihat dari perspektif kesisteman, kualitas hasil atau output yang berupa prestasi olahraga ditentukan oleh kualitas masukan atau input dan kualitas proses yang terjadi. Semuanya harus terjadi dalam kondisi lingkungan sistem yang kondusif yang didukung dengan aturan-aturan yang memungkinkan terciptanya suatu sinergi sehingga menimbulkan momentum pengembangan olahraga.

Cabang olahraga woodball merupakan salah satu cabang olahraga baru yang memang masih asing dan jarang sekali didengar dilingkungan kita. Woodball jugan merupakan olahraga yang sedang berkembang di dunia. Hal ini ditunjang dengan jumlah negara anggota IWbF (International Woodball Federation) hingga 2008 tercatat 29 negara yang tersebar di lima benua. Salah satu dari ke 29 negara tersebut adalah Indonesia. Hingga tahun 2012 Indonesia Woodball Asosiation (IWbA) sudah mempunyai pengurus daerah di 14 Provinsi (Kriswantoro \& Anas, 2012:7)

$$
\text { Woodball adalah olahraga }
$$

permainan luar ruangan yang dimainkan secara perorangan atau tim dengan cara memukul bola secara berangsur-angsur sampai meneroboskan bola ke gawang yang ada pada setiap fairway (lintasan) dengan jumlah pukulan sedikit mungkin. Soetrisno (2011:10) menjelaskan, woodball pertama kali berkembang di Taipe Cina, ditemukan pada tahun 1990 oleh Mr. Ming-Hui Weng dan Mr. Kung $\mathrm{Cu}$ Young. Permainan woodball merupakan cabang olahraga modifikasi dari olahraga golf yang mempertimbangkan unsur-unsur efisiensi biaya dan mempertahankan lingkungan hidup.

Woodball merupakan olahraga yang berprospek di kembangkan di Indonesia, karena olahraga yang mirip golf ini cukup murah dan terjangkau oleh semua kalangan serta relatif mudah. Berdasarkan hasil pra penelitian yang penulis lakukan dilapangan, di Jawa Tengah terdapat 6 Pengcab yag mengikuti olahraga woodball antara lain: Pengcab Kota Boyolali, Semarang, Kudus, Jepara, Kebumen, Tegal. Setiap Pengcab mempunyai tidak banyak atlet, hanya beberapa Pengcab yang mempunyai atlet berprestasi mulai tingkat daerah Nasional bahkan Internasional.

Perkembangan woodball di Jawa Tengah masih belum menyeluruh di lapisan masyarakat. IWbA seharusnya sebagai organisasi Pengprov Jateng yang bertugas mengembangkan prestasi woodball di Jawa Tengah kurang dapat mengembangkan dan menjalankan fungsinya sebagai organisasi. Padahal salah satu fungsi dari organisasi $I W b A$ Pengprov Jateng adalah sebagai sarana sosialisasi dan alat yang diharapkan dapat mempopulerkan woodball di masyarakat Jawa Tengah. Seperti yang diuangkapkan oleh James D Mooney dalam Sutarto, (1992: 21) "Organisasi adalah bentuk setiap perserikatan manusia untuk mencapai tujuan bersama." Lebih lanjut Oliver Sheldon dalam Sutarto (1992: 21) mengemukakan bahwa:

"Organization is the process of so combining the work which individuals or groups have to ferform, provide the faculties necessary for it execution that the 
duties, so formed, provide the best channels for the efficient, sytematic, positive, and co-ordinated application of the available effort."

Definisi diatas menggambarkan bahwa organisasi adalah poses penggabungan pekerjaan yang para individu atau kelompok - kelompok harus melakukan dengan bakat-bakat yang diperlukan untuk melakukan tugas-tugas, sedemikian rupa, memberikan saluran terbaik untuk pemakaian yang efisien, sistematis, positif, dan terkoordinasi dari usaha yang tersedia.

Dengan berdasarkan pada latar belakang yang dikemukanan sebelumnya, maka rumusan masalah yang akan dikemukakan adalah: Bagaimana keberadaan organisasi olahraga woodball di Jawa Tengah, bagaimana upaya mengembangkan olahraga woodball yang dilakukan Pengprov IWbA Jawa Tengah, bagaimana kondisi sumber daya manusia di Pengprov Jawa Tengah untuk mengembangkan olahraga woodball, bagaimana sarana dan prasarana yang dimiliki oleh Pengprov Jawa Tengah, bagaimana penggalian sumber dana oleh Pengprov Jawa Tengah, bagaimana pembinaan prestasi olahraga woodball yang diterapkan di Pengprov Jawa Tengah.

\section{METODE PENELITIAN}

Metode penelitian yang digunakan adalah pendekatan studi deskriptif kualitatif yaitu mendeskripsikan pengembangan olahraga woodball di Provinsi Jawa Tengah. Metode deskriptif dapat diartikan sebagai prosedur pemecahan masalah yang diselidiki dengan menggambarkan atau melukiskan keadaan subjek/objek penelitian (seorang, lembaga, masyarakat, dan lain -lain).

Penelitian ini akan dilakukan di Pengprov Indonesia Woodball Association (IWbA) Provinsi Jawa Tengah. Teknik pengambilan sampel yang digunakan adalah purposive sampling dan snowball sampling. Sumber data dalam penelitian ini meliputi anak tunagrahita, guru pendidikan jasmani, wali kelas, dan orang tua murid.

Teknik Pengumpulan data dilakukan dengan cara mengkaji data dan arsip (content analysis), wawancara mendalam (in-depth interviewing), observasi (observation). Selanjutnya dilakukan reduksi data untuk pemfokusan, penyederhanaan dan kemudian dilakukan deskripsi dalam bentuk narasi yang memungkinkan simpulan penelitian dapat dilakukan. Sedangkan, untuk menetapkan keabsahan data digunakan teknik pemeriksaan dengan empat kriteria yaitu derajat kepercayaan (credibility), keteralihan (transferability), kebergantungan (dependability), dan kepastian (confirmability). Data yang dianalisis secara kualitatif berasal dari data yang diperoleh dari berbagai sumber yaitu wawancara. Tahap analisis data yang dilakukan dalam penelitian ini sebagaimana yang dilakukan yaitu: (1) reduksi data, (2) penyajian data, (3) penarikan kesimpulan, (4) meningkatkan keabsahan hasil, dan (5) narasi hasil analisis.

\section{HASIL DAN PEMBAHASAN}

Berdasarkan pada seluruh rangkaian penelitian dan pengambilan data dari berbagai sumber yang ditemui oleh peneliti maka didapatkan beberapa data yang kemudian menjadi pendukung ketercapaian temuan-temuan penting dalam penelitian ini. Data-data ini diharapkan dapat menjawab rumusan masalah atau juga dapat memberikan banyak informasi yang dapat berguna bagi siapa saja yang membutuhkan. Berikut hasil data yang didapat dari berbagai sumber informasi:

\section{HASIL}

\section{Keberadaan Organisasi Woodball Di Provinsi Jawa Tengah}

Olahraga woodball mulai masuk ke Indonesia pada tahun 2006 saat itu dibawa oleh Tandiono Jacky yang sekarang menjabat sebagai Ketua Umum dan di 
perkenalan di Jawa Tengah pada tahun 2006 sekaligus dengan didirikannya kepengurusan pusat yang dinamakan Indonesia Woodball Association (IWbA) sebagai induk organisasi.

Indonesia Woodball Association (IWbA) membentuk kepengurusan di tiap Provinsi (Pengprov). Salah satunya Pengurus Provinsi Jawa Tengah dan disusul oleh beberapa Pengurus Provinsi lainya, seperti: Pengurus Provinsi Bali, Sumatra Selatan, DIY, Jawa Timur, Jawa Barat, Bangka Belitung, Sumatra Barat, Bengkulu, Lampung, Kalimantan Timur, Kepulauan Riau. Jawa Tengah merupakan Pengprov pertama yang dibentuk oleh $I W b A$. Pengprov Jawa Tengah dibentuk sejak tahun 2007, terbentuknya Pengprov Jawa Tengah karena terpilihnya Indonesia untuk mengadakan Eventt Internasional. Dukungan dari ketua KONI Ibu Rita Subowo untuk menindaklanjuti kegiatan tersebut yang akan diselenggarakan di Kabupaten Boyolali. Dengan dibentuknya Pengurus Provinsi yang ada diharapkan dapat mengembangkan olahraga woodball dengan berbagai cara.

Setelah dibentuknya Pengda Jawa Tengah terbentuklah Pengurus Cabang (Pengcab), diantaranya yaitu Pengcab Kota Semarang, Boyolali, Kudus, Jepara dan Kebumen. Pada kepengurusan Pengprov di Jawa Tengah, terpilihkan Ardhana Ariyanto, S.E sebagai Ketua Umum Pengprov IWbA Jawa Tengah.

Pada dasarnya organisasi merupakan wadah atau tempat dimana tugas utamanya adalah memajukan suatu olahraga baik dari segi kualitas maupun kuantitas. Jawa Tengah selama ini berupaya untuk mengembangkan olahraga woodball, dengan terbentuknya organisasi woodball $I W b A$ diharapkan prestasi, sumberdaya masyarakat dapat berkembang ke arah yang lebih baik. Jawa Tengah juga merupakan Provinsi barometer olahraga woodball yang akan terus melakukan pengembangan. Pengurus Provinsi woodball terus menerus berupaya membuat kepengurusan cabang yang berada di setiap kabupaten yang ada di Jawa Tengah yang belum mengenal olahraga woodball.

\section{Upaya Pengembangan Cabang Olahraga Woodball Yang Dilakukan Pengprov IWbA Jawa Tengah}

Untuk pengembangan suatu cabang olahraga membutuhkan faktor-faktor penunjang, terutama untuk pengembangan kearah peningkatan prestasi. Faktor-faktor tersebut yaitu organisasi dan manajemen, pembinaan, dan latihan, pelatihan, fasilitas dan alat-alat perlengkapan (sarana dan prasarana), atlit, dana (biaya) dan hubungan kerjasama antara lnstansi yang terkait. Begitu pula untuk perkembangan permainan woodball membutuhkan faktorfaktor yang disebutkan di atas, baik pengembangan di lembaga pendidikan, di lembaga pemerintahan, swasta dan di masyarakat (daerah).

Adapun tujuan utama yang di agendakan Pengprov IWbA Woodball telah adanya upaya pengembangan di Jawa Tengah dengan terbentuknya: Pengurus Daerah Jawa Tengah (Pengprov Jateng) Sebagai Provinsi yang selalu menjadi barometer perkembangan cabang olahraga Woodball pada tingkat Nasional, Jawa Tengah tidak ketinggalan untuk ikut serta mengembangkan cabang olahraga baru seperti Woodball sekaligus menyokong prestasi Nasional.

Pembentukan pengurus daerah pun dilakukan untuk kemudian dilantik pada tahun 2007 oleh Presiden IWbA (Tandiono Jecky). Seiring dengan perkembangan, Ardhana Arifianto ditunjuk sebagai Ketua Pengprov IWbA Jateng, Pengdam IV Diponegoro sebagai pembina bersama Rektor Undip, Novan Hari Prasetyo dan Wijaya Arief dilantik sebagai wakil ketua, sementara Gumilag Febriyansyah sebagai sekretaris umum. Beberapa anggota pengurus lainnya menunjang kinerja mereka.

Pengurus Daerah Jawa Tengah IWbA Olahraga woodball tidak berhenti - henti mengembangkan dan mensosialisasikan 
Olahraga woodball ke masing-masing daerah (pelosok daerah) dalam tahap upaya pengembangan. Olahraga woodball telah berkembang secara pesat keberbagai macam pelosok daerah atau kabupaten.

$$
\text { Olahraga woodball dapat }
$$

berkembang dan menjadikan daya tarik masyarakat lebih tinggi untuk mengenal olahraga woodball. Semakin berkembangnya olahraga woodball di Jawa Tengah, maka mempunyai kecenderungan untuk bersaing di dunia olahraga dalam mencapai prestasi dan berkemungkinan besar upaya pengembangan olahraga tersebut juga mempunyai kaitan dengan minat masyarakat terhadap olahraga woodball, yang menunjukkan bahwa semakin adanya upaya pengembangan secara berlanjut, maka semakin besar pula kecenderungan minat masyarakat untuk terlibat dan mengenal olahraga woodball. Peluang masyarakan Jawa Tengah dalam hal intansi pemerintahaan yang terkait baik sekolah, perguruan tinggi merupakan suatu kesempatan dan peluang besar untuk menjadi atlit olahraga woodball.

\section{Kondisi Sumber Daya Manusia Di Pengprov Jawa Tengah Untuk Mengembangkan Olahraga Woodball}

Kondisi sumber daya manusia yang berperan dalam suatu organisasi untuk tetap bersinergi menjalankan roda organisasi. Keberadaan pelatih, atlet, wasit dan pengurus merupakan suatu indikator penentu keberhasilan organisasi IWbA Jawa Tengah dalam mengembangkan olahraga Woodball.

Dari penelitian yang terkait dengan kepengurusan IWbA Jawa Tengah, struktur kepengurusan $I W b A$ Jawa Tengah tersusun sesuai arahan pengurus besar PB $I W b A$ dan kebutuhan di Pengprov. Mulai dari ketua, wakil ketua, sekretaris dan bendahara, serta bidang-bidangnya semua tersusun dan dijabat oleh orang yang berkompeten dibidangnya. setiap anggota yang menjabat mempunyai masa kepempinan selama lima tahun, setelah masa bakti selesai Pengprov selalu melakukan pemilihan ulang yang dinamakan Musda (musyawarah daerah) menghasilkan pengurus baru dengan masa bakti yang baru, pemilihan tersebut menjadi agenda rutin tiap lima tahun sekali.

Terdapat beberapa pelatih di setiap daerah Pengprov Woodball Jawa Tengah, namun masih banyak yang tidak banyak mempunyai lisensi pelatih Nasional ataupun Internasional. Setiap Pengcab di Jawa Tengah mempunya lebih dari lima klub yang berkembang, dan juga ada banyak pelatih yang bertanggung jawab untuk proses pembinaan. Jumlah pelatih Woodball di Jawa Tengah relatif banyak dilihat dari perkembangan klub di tiap Pengcab, namun tidak banyak klub mempunyai pelatih yang berlisensi. Dari data dan wawancara yang peroleh di $I W b A$ mengemukakan bahwa disetiap diadakan diklat, pelatihan ataupun penataran yang diadakan oleh pengurus pusat, dari 50 peserta yang ada peserta dari Pengprov Woodball Jawa Tengah hanya mendaftar 2 sampai dengan 3 orang tiap kali penyelenggaraan.

Jawa Tengah mempunyai potensi atet yang memiliki prospek yang bagus. Banyak atlet yang lahir dari Jawa Tengah dan mewakili Indonesia ke kancah Internasional. Bahkan peringkat 1 dunia olahraga woodball telah di sandang oleh atlet berasal dari Jawa Tengah. Atlet Indonesia berhasil menorehkan berbagai medali di ajang Nasional bahkan sampai ke Internasional.

\section{Sarana Dan Prasarana Yang Dimiliki Pengprov Jawa Tengah}

Pengprov Jawa Tengah sudah mempunyai sarpras yang sesuai dengan standar yang berlaku untuk menunjang pengembangan dan pembinaan prestasi selama ini. Setiap atlet yang melakukan pembinaan atau pelatihan di Pengprov ataupun di klub sudah memiliki peralatan pribadi seperti malet (tongkat pemukul), bola dan juga gawang (gate). 
Namun ada beberapa kendala dalam standarisasi alat yang diberika oleh $I W b A$ belakangan ini. IWbA mengeluarka peraturan baru atau setandarisasi peralatan yang berkaitan dengan pemakaina peralatan yang digunakan oleh atlet atau peserta pada saat mengikuti pertandingan Nasional. Peraturan terebut sangat memberatkan atlet yang berada di daerah dan atlet yang tidak mempunyai tingkat perekonomian tinggi. Pasalnya standarisasi tidak berdasarkan jenis dan ukuran namun berdasarkan merk yang dimiliki oleh salah satu pihak tertentu. IWbA sebagai induk organisasi woodball seharusnya dapat mempertimbangkan dn juga mengkaji ulang mengenai peraturan yang memberatkan dan menguntungkan salah satu pihak tersebut demi perkembangan olahraga woodball khususnya di Provinsi Jawa Tengah.

\section{Penggalian Sumber Dana Oleh Pengprov Jawa Tengah}

Ketersediaan dana dari Pengprov Woodball Jawa Tengah masih sangat minim. Didalam olahraga woodball baik dari Pengcab maupun dari Pengprov woodball Jawa Tengah berusaha untuk mencari himpunan dana sendiri, dan berusaha semaksimal mungkin untuk mengembangakan olahraga ini. Pengurus pusat IWbA selalu bekerja keras untuk terus mengembangakan olahraga woodball baik dari segi sumber daya manusia, sarana prasarana dan pembinaan prestasi. Ketua umum $I W b A$ bapak Tandiono Jecky juga tak henti-hentinya membina sumber daya yang ada dengan mengadakan pelatihan rutin dan juga membina atlet supaya terus berkiprah didunia Nasional maupun Internasional, walapun belum mendapatkan perhatian dari pemerintah.

\section{Pembinaan Prestasi Olahraga Woodball Yang Diterapkan Di Pengprov Jawa Tengah}

Beberapa cara letah dilakukan Pengprov ataupun Pengcab untuk membina atlet. Proses pembinaan yang dilakukan Pengprov ataupun Pengcab yang diberikan salah satunya memang berdasarkan pemahaman "dari atlet kembali ke atlet". Beberapa Pengcab woodball Jawa Tengah sering mengadakan pertandingan antar klub ataupun pertandingan daerah "monly game" yang diikuti oleh atlet dari Pengcab namun tidak menutup kemungkinan atlet dari daerah lain mendominasi. Pertandingan itu dilakukan dengan kondisi pendanaan yang sederhana, dengan membayar uang pendaftaran mengelola pertandingan sendiri dan nantinya hasil yang didapat akan diserahkan atau dikembalikan kepada atlet woodball yang mendapatkan juara para kompetisi tersebut.

\section{PEMBAHASAN}

\section{Keberadaan Organisasi Woodball Di Jawa Tengah}

Pengurus Provinsi Jawa Tengah (Pengprov Jateng) sebagai Provinsi yang selalu menjadi barometer perkembangan cabang olahraga di tingkat Nasional, Jawa Tengah tidak ketinggalan untuk ikut serta mengembangkan cabang olahraga baru seperti woodball sekaligus menyokong prestasi Nasional. Di Jawa Tengah, permainan ini (woodball) mulai diperkenalkan pada tahun 2006 oleh Tandiono Jecky dan Dr. Nugroho Widiasmadi, sebagai Presiden dan Wakil Presiden Indonesia Woodball Association $(I W b A)$.

Pembentukan pengurus Provinsi pun dilakukan untuk kemudian dilantik pada tahun 2007 oleh Presiden IWbA (Tandiono Jecky). Seiring dengan perkembangan, Ardhana Arifiyanto ditunjuk sebagai Ketua Pengprov IWbA Jateng, Novan Hari Prasetyo dan Wijaya Arief dilantik sebagai wakil ketua, sementara Gumilag Febriyansyah sebagai sekretaris umum. Beberapa anggota pengurus lainnya menunjang kinerja mereka.

Pengurus Provinsi IWbA Jawa Tengah olahraga woodball tidak berhenti henti mengembangkan dan mensosialisasikan olahraga woodball ke 
masing-masing daerah (pelosok daerah) dalam tahap upaya pengembangan. Olahraga woodball telah berkembang secara pesat ke berbagai pelosok daerah atau kabupaten.

Pengprov Jateng sekarang telah memiliki pengurus cabang olahraga Woodball diantaranya Pengcab Semarang, Boyolali, Jepara, Kudus, Kebumen. Sementara ini Pengprov Jawa Tengah memiliki 5 Pengurus Pengcab yang akan membantu untuk mensosialisasikan olahraga woodball tersebut kepada masyarakat Jawa Tengah dalam upaya pengembangan olahraga woodball.

\section{Upaya Pengembangan Cabang Olahraga Woodball Yang Dilakukan Pengprov IWbA Jawa Tengah}

Olahraga woodball berkembang dengan sangat pesat. Dari tahun 2006 olahraga woodball masuk ke indonesia sampai terbentuklah pengurus pusat, $\mathrm{PB}$ $I W b A$ sudah mempunyai 12 pengurus daerah, salah satunya pengurus daerah jawa tengah. Di Jawa Tengah olahraga ini tergolong berkembang, terbukti dengan adanya lima pengurus cabang yang sudah terbentuk. Pengurus daerah woodball jawa tengah mempunyai peran untuk mengembangan olahraga woodball di semua lapisan masyarakat. Beberapa upaya telah dilakukan untuk mengembangkan olahraga ini, salah satunya dengan membentuk pengurus cabang untuk menyokong prestasi, membina potensi sumber daya manusia yang ada, mensosialisasikan olahraga woodball ke semua lapisan masyarakat baik didalam lembaga pendidikan, di lembaga pemerintahan, swasta dan di masyarakat (daerah), mengadakan pertandingan atau event untuk menarik minat dan bakat masyarakat terhadap olahraga ini dan juga mengadakan serangkaian kegiatan di berbagai lembaga pendidikan seperti SD, SMP SMA, dan Universitas.

Pembinaan atlet terus dilakukan pengda woodball Jawa Tengah.
Penyelenggaraan kejuaraan dan melakukan penataran bagi seorang wasit dan pelatih merupakan agenda wajib yang dilakukan oleh pengurus pusat dan pengurus daerah. Dengan menyelenggarakan berbagai pertandingan, pemain atau atlet woodball bisa semakin mengasah kemampuan untuk bermain woodball. Selain itu pengurus pusat dan pengurus daerah melakukan agenda tahunan yaitu penataran wasit dan pelatih. Selain untuk mengetahui tentang permainan woodball pelatihan diadakan sebagai media pengembangan olahraga woodball dan juga untuk mengambangkan potensi pelatih dan atlet yang ada di berbagai daerah.

Disamping itu Pengprov Jateng berupaya mengembangkan olahraga woodball kepada Pengcab-pengcab yang ada di Jawa Tengah untuk membuat klub team woodball sebagai ajang pembinaan atau perekrutan atlet woodball Jateng Menuju Event yang akan datang.

Semakin berkembangnya olahraga woodball di Jawa Tengah, maka mempunyai kecenderungan untuk bersaing di dunia olahraga dalam mencapai prestasi dan berkemungkinan besar upaya pengembangan olahraga tersebut juga mempunyai kaitan dengan minat masyarakat terhadap olahraga woodball, yang menunjukkan bahwa semakin adanya upaya pengembangan secara berlanjut, maka semakin besar pula kecenderungan minat masyarakat untuk terlibat dan mengenal olahraga woodball. Peluang masyarakan Jawa Tengah dalam hal instansi pemerintahan yang terkait baik sekolah, perguruan tinggi merupakan suatu kesempatan dan peluang besar untuk menjadi atlet olahraga woodball.

\section{Kondisi Sumber Daya Manusia Di Pengprov Jawa Tengah}

Sumber daya manusia adalah model dasar mengembangkan olahraga dan peningkatan prestasi olahraga. Pengembangan olahraga prestasi kompleks, untuk itu di perlukan sumberdaya manusia yang berkualitas. 
Komponen sumberdaya manusia yang dimaksudkan adalah atlet, pelatih dan pengurus cabang olahraga.

Setiap organisasi olahraga sangat tergantung pada orang-orang yang mengambil peran dari organisasi misalnya; administrator, pengumpul atau penyandang dana, perencana, wasit, pelatih, atlet, dan ahli sport medicine. Komponen-komponen sumber daya manusia ini sangat menentukan tingkat keberhasilan pengembangan olahraga di suatu daerah. Begitu pula untuk pengembangan permainan olahraga woodball di Jawa Tengah juga membutuhkan kondisi sumber daya manusia yang memadai.

Sumber daya manusia merupakan bagian yang penting dalam dunia keolahragaan secara umum dan lebih khususnya pada cabang olahraga woodball. Sumber daya manusia yang berperan dalam suatu organisasi untuk tetap bersinergi menjalankan roda organisasi. Keberadaan pelatih, atlet, wasit, dan pengurus merupakan suatu indikator penentu keberhasilan organisasi IWbA Jawa Tengah dalam mengembangkan olahraga woodball.

Berdasarkan dari hasil penelitian yang didapatkan bahwa di Provinsi Jawa Tengah terdapat pengurus cabang olahraga woodball. terdapat ketua, wakil ketua, sekretaris dan bendahara serta bidangbidang yang tersusun dan dijabat oleh orang yang berkompeten didalamnya untuk mengembangkan olahraga woodball di Provinsi Jawa Tengah. Musyawarah daerah atau Musda diadakan setiap lima tahun sekali untuk me-refresh atau menyusun kepengurusan baru. Pengprov $I W b A$ Jawa Tengah juga mengadakan rapat kerja (Raker) bulanan atau tahunan berama anggota yang lain dan juga pengurus cabang IWbA Jawa Tengah untuk menyusun program kerja yang akan dilaksanakan tiap tahunya sebagai wujud upaya pengembangan olahraga woodball. Setiap anggota kepengurusan woodball turut ambil andil dalam pengembangan olahraga ini, segala upaya yang berkaitan dengan pengembangan dilakukan mulai dari program yang akan digunakan, pembinaan sumber daya manusia, sarana prasarana, pendanaan, dan pembinaan prestasinya.

Pelatih

berperan

dalam

pengembangan olahraga woodball

khususnya di Provinsi Jawa Tengah. Tanpa adanya seorang pelatih yang berkompeten prestasi woodball tidak akan bisa mengalami peningkatan. Pengurus pusat $I W b A$ bekerja sama dengan pengurus Provinsi selalu memberikan pembinaan untuk sumber daya manusia yang ada, salah satunya pelatih dan wasit. Kegiatan tersebut terselenggara setiap satu tahun sekali. Di Provinsi Jawa Tengah ada beberapa pelatih yang sudah mendapatkan lisensi Nasional dan bahkan lisensi Internasional. Pengurus pusat IWbA terkadang mengikutsertakan sumber daya manusia berupa pelatih ke luar negeri guna mendapatkan pembinaan atau penataran oleh pakar yang berpengalaman, namun banyak juga pelatih di Provinsi Jawa Tengah belum mendapatkan sertifikat. Hal tersebut dikarenakan tidak ada kesediaan dana untuk mengikuti pelatihan yang diadakan, pelatih di Pengcab Jawa Tengah mengaku keberatan dengan biaya yang harus dikeluarkan untuk mengikuti pelatihan dan mendapatkan lisensi pelatih maupun wasit.

Jumlah atlet woodball di Provinsi Jawa Tengah terus menglami peningkatan. Pembibitan atlet terus dilakukan oleh setiap Pengcab yang ada untuk terus mengembangkan olahraga woodball. Setiap Pengcab IWbA Provinsi Jawa Tengah terus menerus melakukan pembinaan guna mencetak dan mengembangkan prestasi. Potensi atlet woodball Provinsi Jawa Tengah sangatlah bagus hal tersebut terbukti dengan prestasi yang diraih oleh atlet Jawa Tengah baik pertandingan di tingkat daerah, Nasional maupun Internasional. Beberapa atlet woodball Provinsi Jawa Tengah telah menjuarai berbagai kejuaraan junior maupun senior yang diadakan oleh setiap 
daerah dan putra dan putri atlet asal Jawa Tengah mendapatkan peringkat satu dunia dan peringkat ke tiga. Prestasi tersebut sangat membanggakan bagi pengurus Provinsi IWbA Jawa Tengah.

Dengan kondisi sumber daya manusia di Pengprov IWbA Jawa Tengah tersebut diharapkan perhatian dan dukungan pemerintah semakin komplek, karena dengan dukungan yang diberikan oleh pemerintah turut menunjang kemajuan perkembangan olahraga woodball khususnya di Provinsi Jawa Tengah.

\section{Sarana Dan Prasarana Yang Dimiliki Pengprov Jawa Tengah}

Lapangan merupakan salah satu hal terpenting dalam proses pembinaan, tanpa adanya lapangan olahraga woodball tidak akan berkembang, berpotensi, maupun berkualitas. Lapangan merupakan kebutuhan pokok yang harus ada di setiap cabang atau kabupaten di tiap Provinsi. Provinsi Jawa Tengah merupakan Provinsi yang mempunyai cukup lahan untuk mengembangkan olahraga woodball. Pada dasarnya olahraga woodball tidak memerlukan lahan khusus untuk proses pembinaan, dengan menggunakan lahan taman kota, alun-alun, lapangan bola bahkan lahan di tempat obyek wisatapun bisa digunakan untuk berlatih atau membina olahraga woodball. Dalam permainan woodball tidak mengharuskan menggunakan lapangan yang berkontur tanah datar atau halus sepeti olahraga golf, tanah berkontur gelombang atau berbukit pun bisa digunakan untuk bermain woodball.

Beberapa kendala muncul seiring perkembangan peraturan yang ada salah satunya peraturan mengenai pemakaian peralatan atau standarisasi peralatan pada saat mengikuti kejuaraan Nasional ataupun Internasional tidak ditentukan oleh berat, panjang, dan juga ukuran yang lainnya namun menggunakan standarisasi merek tertentu. Dari salah satu Pengcab di Provinsi Jawa Tengah menyebutkan bahwa dalam peraturan yang dibuat oleh pengurus pusat bahwa atlet dari tiap Pengcab pada saat mengikuti kejuaraan Nasional maupun Internasional harus memiliki peralatan berdasarkan merek brand tertentu. Hal tersebut dianggap sangat memberatkan atlet yang ingin berprestasi didunia woodball, pasalnya bukan standarisasi berdasarkan ukuran namun berdasarkan merek tertentu. Olahraga woodball merupakan olahraga yang tergolong murah dan tujuan pengurus mengembangkan olahraga ini supaya semua lapisan masyarakat bisa ikut bermain di dalamnya. Pengurus cabang berharap peraturan yang memberatan tersebut dikaji ulang sehingga dapat membantu perkembangan dan prestasi atlet woodball di tiap daerah di Provinsi Jawa Tengah.

Selain terkendala mengenai peraturan baru yang ditetapkan ada beberapa kendala tentang sarana lapangan yang digunakan. Di Provinsi Jawa Tengah terdapat berbagai tempat yang bisa digunakan untuk bermain woodball, namun tiap Pengcab tau pengurus cabang IWbA Jawa Tengah tidak memiliki lapangan yang di kelola oleh pengurus woodball. selama ini pengurus cabang bekerja sama dengan beberapa pihak mengenai pengunaan lapangan yang digunakan untuk pembinaan atlet. Misalnya bekerja sama dengan Universitas, DinasPariwisata, Sekolah dan perorangan yang mempunyai lahan yang bisa digunakan. Sampai sekarang dukungan dari pemerintah mengenai sarana dan prasarana masih sangat kurang, setiap Pengcab mengharapkan adanya penyediaan lahan yang digunakan untuk pengelolaan sumber daya manusia. Beberapa kepengurusan cabang masih menggunakan rumah pribadi atau masih numpang dengan pengurus cabang olahraga lainya. Melihat potensi dan prestasi atlet woodball di Provinsi Jawa Tengah khususnya, pemerintah seharusnya memikirkan mengenai sarana prasarana tersebut guna mambantu kemajuan dan pengembangan olahraga woodball. 


\section{Penggalian Sumber Dana Oleh Pengprov Jawa Tengah}

Penyediaan dana dan pendapatan sumber-sumber dana yang diperoleh pengurus Provinsi masih sangat minim. woodball merupakan olahraga baru, perhatian pemerintah mengenai pendanaan masih tergolong kurang. Terkadang pemerintah memberikan bantuan berupa dana insentif kepada Pengprov untuk pembinaan atlet woodball di Provinsi Jawa Tengah, namun kenyataanya di lapangan dana tersebut tidak cukup untuk mebina keseluruhan kebutuhan atlet yang ada.

Dari awal masuknya olahraga woodball di Indonesia sampai terbentuknya pengurus Provinsi IWbA di Jawa Tengah, bapak Tandiono Jacky sebagai salah satu sekjen International Woodball Federation (IWbF) dan juga menjabat sebagai ketua umum PB IWbA melakukan pembiyayaan menggunakan dana pribadi. Dana di dapat dari wirausaha dibidang peralatan woodball yang diberi nama "jacking" yang sudah mendunia. Mulai dari pembentukan organisasi atau pengurus Provinsi, pembinaan sumber daya manusia sampai pada prestasi atlet woodball bliau sangat berperan penting didalamnya. Pada awal tahun pengembangan olahraga woodball bapak Tandiono Jacky melatih atlet dan kemudian membawa atlet ke luar negeri untuk mengasah kemampuaan bermain woodball. Banyak dukungan yang diberika dari beliau untuk mengembangkan olahraga ini didunia Nasional maupun Internasional. Dukungan royalty atau tali asih juga sering diberikan kepada atlet yang berprestasi. Hal tersebut dilakukan sebagai pendorong dan motivasi atlet untuk terus berprestasi.

Pengprov maupun Pengcab terus berusaha mendapatkan sumber pendanaan lain. Beberapa cara dilakukan salah satunya terus menghimpun dana mengajukan anggaran untuk membina sumber daya manusia yang ada. Walaupun yang didapat tidak sesuai dengan yang diharapkan pengurus Provinsi berupaya supaya kegiatan atau program yang telah disusun dapat berjalan sebagaimana mestinya.

\section{Pembinaan Prestasi Olahraga Woodball Yang Diterapkan Di Pengprov Jawa Tengah}

Pengurus Provinsi IWbA Jawa Tengah menyusun berbagai program untuk membina atlet berprestasi. Salah satu program yang dibuat adalah melakukan pembinaan bersama dengan mengadakan latihan bersama antar klub yang ada di tiap Pengcab $I W b A$ Provinsi Jawa Tengah dan mengadakan pertandingan-pertandingan antar klub dan Pengcab yang diberi nama (monly game). Kurangnya ketersediaan dana yang dimiliki Pengprov IWbA Jawa Tengah membuat Pengprov tidak mengadakan pembinaan prestasi secara khusus seperti diadakannya Pusat Pembinaan dan Latihan olahraga Pelajar (PPLP) atau sejenisnya. Setiap atlet woodball di Provinsi Jawa Tengah melakukan pembinaan prestasi di klubnya masing-masing, Pengprov hanya memberikan fasilitas pembinaan seperti perijinan pertandingan, mengadakan Event, seleksi, mengontrol dan memberikan dukungan seadanya. Pengprov IWbA Jawa Tengah hanya melakukan pembinaan khusus atau traning center (TC) kepada atlet yang terpilih untuk mengikuti kejuaraan Nasional atau Internasional yang nantinya mewakili atau membawa nama Provinsi Jawa Tengah. Kejuaraan yang menjadi program rutin seleksi daerah Pengprov IWbA Jawa Tengah sebagai partisipan secara rutin adalah pelaksanaan kejuaraan Nasional seperti kejuaraan Nasional super series, woodball open, Pekan Olahraga Nasional dan kejuaran Internasional: Asean Beach Game, Woodball International Ship, Asia University, world university. Pengprov IWbA Jawa Tengah selalu mengawasi atau mengontrol prestasi atlet woodball Jawa Tegah, mulai dari minat, bakat, prestasi, 
peringkat dan perkembangan sumber daya manusia yang ada. Sebelum melakukan traning center Pengprov IWbA melakukan seleksi terhadap semua atlet woodball yang ada di Provinsi Jawa Tengah, pemilihan atlet tersebut berdasarkan peringkat Nasional yang didapat dan juga kualitas dan kuantitas atlet. Setiap atlet yang dikirimkan oleh Pengcab masingmasing di kumpulkan dan diseleksi di Pengprov yang berada di semarang, dari seleksi tersebut didapatkan atlet yang benar-benar berkualitas untuk menjadi wakil dari Pengprov IWbA Jawa Tengah.

Dengan pembinaan yang selama ini dilakukan Pengprov Jawa Tengah berhasil mencetak banyak prestasi. Prestasi atlet woodball Jawa Tengah sudah tidak bisa diragukan lagi. Beberapa kali mengikuti Event Nasional maupun Internasional atlet woodball Jawa Tengah sering mendapatkan medali. Hal tersebut terbukti dengan Provinsi Jawa Tengah menjadi juara umum ketika mengikuti eksibisi cabang olahraga woodball pekan olahraga Nasional PON XIX Tahun 2016 di lapangan Pusdikav Pandalarang Bandung, dengan perolehan 5 emas, 4 perak dan 2 perunggu. Bahkan peringkat satu woodball dunia telah diraih oleh atlet woodball asal Jawa Tengah Indonesia, Aharis Sumaryanto dan Ika Yulianingsing sebagai peringkat tiga putri dunia.

\section{KESIMPULAN}

Kesimpulan yang dimunculkan dalam penelitian ini merupakan temuantemuan penting yang peneliti temukan berdasarkan data dan analisis juga pembahasan yang sebaik-baiknya, dan temuan-temuan tersebut berupa:

Keberadaan organisasi olahraga woodball di Jawa Tengah belum lama, pada tahun 2006 Induk orgaisasi woodball IWbA (Indonesia Woodball Association) telah dibentuk yang berada di kota Semarang Provinsi Jawa Tengah dan tahun 2008 Pengprov IWbA Jawa Tengah di bentuk sebagai salah satu wadah dan sarana untuk mengawasi dan mengembangkan olahraga woodball di Jawa Tengah. Organisasi woodball di Provinsi Jawa Tengah terstruktur dan tersusun sebagaimana mestinya. Melalui pengurus organisasi IWbA di Provinsi Jawa Tengah diharapkan dapat mengembangkan olahraga woodball.

Upaya mengembangkan olahraga woodball yang dilakukan Pengprov IWbA Jawa Tengah antara lain dengan membentuk pengurus cabang woodball, melakukan sosialisasi untuk mengenalkan dan menggali minat serta bakat olahraga woodball, pembinaan atlet, mengadakan Event dan juga penataran pelatih dan wasit.

Kondisi sumber daya manusia di Pengprov Jawa Tengah untuk mengembangkan olahraga woodball mulai dari pelatih, wasit, atlet dan pengurus organisasi sangatlah bagus. Pengprov IWbA Jawa Tengah terus menerus melakukan berbagai cara untuk meningkatkan sumber daya manusia yang ada, dengan melakukan pembinaan dan juga mengadakan berbagai kejuaraan. Prestasi atlet woodball Jawa Tengah mengalami peningkatan yang sangat signifikan, terbukti dengan perolehan medali di setiap pertandingan yang diikuti baik tingkat Nasional maupun Internasional dan juga terdapat faktor pendukung pembinaan dan pelatihan yang diberikan pengurus pusat terhadap pelatih dan atlet.

Sarana dan prasarana yang dimiliki oleh Pengprov Jawa Tengah sangat memadai untuk melakukan pembinaan prestasi atau mengembangkan prestasi. Namun dalam hal ini penggunaan lapangan masih harus bekerjasama dengan pihak lain seperti dinas pariwisata, universitas, dan perorangan, karena belum adanya lahan yang dikelola secara pribadi oleh pengurus yang digunakan sebagai sarana latihan dan pengembangan prestasi olahraga woodball.

Penggalian sumber dana yang dilakukan oleh Pengprov Jawa Tengah masih mengalami beberapa kendala. 
Perhatian pemerintah dalam hal pendanaan olahraga woodball masih kurang. Dana yang telah diperoleh masih sangat kurang untuk melakukan berbagai kegiatan untuk pengembangan olahraga woodball di Provinsi Jawa Tengah. Selain mengharap bantuan dari pemerintah untuk melakukan penggalian dana Pengprov bekerja sama dengan berbagai pihak seperti pengurus pusat atau PB IWbA, donatur dan juga seponsor.

Pembinaan prestasi olahraga woodball yang diterapkan di Pengprov Jawa Tengah berjalan dengan cukup baik. Beberapa upaya telah dilakukan oleh Pengprov IWbA Jawa Tengah untuk dapat memaksimalkan prestasi atlet woodball, salah satunya dengan mengadakan berbagai kejuaraan dan pembibitan di berbagai klub. IWbA Jawa Tengah belum mempunyai pusat pelatihan woodball namun pelatihan atlet dilakuan di klubklub yang ada di berbagai Pengcab di Jawa Tengah. sampai saat ini Pengprov memberikan fasilitas berupa perijinan, menyusun berbagai kegiatan pembinaan, dan juga melakukan pelatihan bagi atlet yang akan diikut sertakan untuk mengikuti pertandingan Nasional atau Internasional.

\section{DAFTAR PUSTAKA}

Bangun, Wilson. (2008). Industri manajemen. PT. Refika Aditama. Bandung.

Chang, Baosheng. (2008). The international woodball referee workshop. Taiwan: International Woodball Federation.

Chang, Baosheng. (2009). Jurnal of woodball. No 16. Taiwan: IWbF News Letter.

Corobiru's. (2007). Pengertian manajemen keuangan.

(http//www.ManajemenKeuangan)

Departemen Pendidikan Nasional. (2009). Pedoman penulisan karya ilmiah.
Bandung: Universitas Pendidikan Indonesia.

Dwiyogo, Wasis, D., Kriswantoro. (2009). Olahraga woodball. Malang: Wineka Media.

Evans., William, M. (1988). Organization theory: research and design. NY: McMillan.

Hadari, N. (2003), Manajemen strategik organisasi non profit bidang pemerintahan. Gajah Mada University Press: Yogyakarta.

Handoko., Hani, T. (1999). Manajemen olahrga edisi 2. BPFE: Yogyakarta.

Harsuki, H. (2003). Perkembangan olahraga terkini: kajian para pakar. PT. Raja Grafindo Persada : Jakarta.

Harsuki, H. (2003). Pengantar manajemen olgraga. Pt. Raja Grafindo Persada: Jakarta.

Harsuki, H. (2003). Manajemen olahraga. Jakarta: PT Raja Grafindo Persada.

Irdiyana, P. (2010). Devinisi olahraga woodball. Bandung.

Imanudin, I. (2008). Ilmu kepelatihan keolahragaan. Bandung:FPOK UPI.

IWBA. (2009). Sejarah dan asal usul woodball [On Line]. Tersediia: http://forum.pasarsolo.com/olahraga otomotif/woodball/5/?wap2 [20 Juni 2016] 15:25 WIB.

James, R., Christopher. (1995). Training manajemen. concept and applications. Mosby.

Kemenegpora. (2007). Undang-undang Republik Indonesia nomor 3 tahun 2005 tentang sistem keolahragaan 
nasional. Jakarta: Biro Humas dan Hukum.

Kriswantoro. (2009). Woodball-woodball berpotensi dipertandingkan pada PON 2012 [On Line]. Tersedia: http://tabanan.baliwoodbal.org/ [20 Juni 2016] 15:30.

Koentjaraningrat. (1997). Metode-metode penelitian masyarakat. Jakarta: Gramedia Pustaka Utama.

KONI. (1997). Sistem pembinaan atlet berprestasi. Proyek Garuda Emas. Jabar.

Kusmaedi. (2002). Olahraga rekreasidan olahraga tradisional. FPOK Universitas Pendidikan Indonesia: Bandung.

Malayu, S., Hasibuan. (2000). Manajemen sumber daya manusia. PT. Gunung Agung: Jakarta.

Margono. (2000). Metodologi penelitian pendidikan. Jakarta : Rineka Cipta.

Mathis, R. L., dan Jackson J, H. (2002). Manajemen sumber daya manusia. SalembaEmpat. Jakarta.

Miles., Matthew B., Huberman, M, A. (1984). Analisis data kualitatif. Buku sumber tentang metode-metode baru. Jakarta: Universitas Indonesia Press.

Milles, Matthew B., Huberman. (2007). Analisis data kualitatif buku sumber tentang metode-metode baru. Jakarta: Universitas Indonesia

Moh, Nazir. (1983). Metode Arikunto, Suharsimi. (2006). Prosedur penelitian suatu pendekatan praktik. Jakarta: Rineka Cipta.
Moleong, Lexy, J. (2004). Metodologi penelitian kualitatif. Bandung: PT Remaja Rosdakarya.

Nasution, S. (1996). Metode penelitian naturalistik kualitatif. Bandung: Tarsito Penelitian. Jakarta: Ghalia Indonesia.

Rusli, Lutan. (2001). Penelitian pendidikan olahraga. Bandung.

Soetrisno, D. (2008). Peraturan permainan woodball. Semarang: Indonesia Woodball Association.

Stoner, J, A. (1986). Manajemen. Jakarta: Erlangga.

Soepartono. (2000). Sarana dan prasarana olahraga. Departemen Pendidikan dan Kebudayaan: Jakarta.

Suharsimi, A. (2006). Prosedur penelitian suatu pendekatan praktik. Jakarta: Rineka Cipta.

Sugiono. (2008). Metode penelitian kuantitatif kualitatif dan $R \& D$. Bandung : CV. ALFABETA.

Sugiyono. (2013). Metode penelitian pendidikan pendekatan kuantitatif, kualitatif, dan $R \& D$. Bandung: Alfabeta.

Sutarto. (1992). Dasar-dasar organisasi. Yogyakarta: Gadjah Mada University Press.

Tandiono, J. (2009). Asal usul olahraga woodball? [On Line]. Tersedia: http://harianjoglosemar.com/berita/a sal-usul-woodbal-4711,html [20 Juni 2016] 15:25 WIB.

Terry, G, R. (1986). Principle of management. Illinois Richard: D. Irwin, Inc. Homewood. 
JPOS (Journal Power Of Sports), 1 (1) 2018, (40-54)

Available at: http://e-journal.unipma.ac.id/index.php/JPOS

Mega Widya Putri ${ }^{1}$, Resty Agustriyani ${ }^{2}$, Sugiyanto $^{3}$, Kiyatno ${ }^{4}$

Wasis, D, D. (2015). Bermain woodball.

Semarang: Indonesia Woodball

Association. 